\title{
Epistemology, Logic and Metaphysics in Pre-Modern India: New Avenues for the Study of Navya-Nyāya
}

\author{
Hugo David ${ }^{1,2} \cdot$ Jonathan Duquette ${ }^{3}$
}

Published online: 5 June 2021

(C) The Author(s), under exclusive licence to Springer Nature B.V. 2021

The six essays in this issue present a significant sample of current research on the history of Navya-Nyāya ("New Logic") or Tarkaśāstra ("the Science of Reasoning"), no doubt one of the most dynamic fields of research on Indian philosophy nowadays. All of them help us better understand the considerable changes that occurred in the Indian philosophical landscape after the alleged "birth" of the school between the time of Udayana (11 th century) and that of Gangeśa (14th century). Paradoxically, perhaps, for a school so fond of precise definitions, no univocal characterisation of Navya-Nyāya has so far reached a true consensus, despite repeated attempts. ${ }^{1}$ The compound itself, navyanyāya, is not attested in Sanskrit at an early date, and the very mention of "new thinkers" (navyāh) by Gangeśa and his followers is not normally made in reference to their own philosophical school. Still, it is undeniable that major changes took place in Nyāya-Vaiśeșika in the first centuries of the second millennium. The mere fact that works produced in that branch of knowledge after Udayana far outnumber those of the earlier period-even considering the comparatively small number of texts available in printed editions - suggests a flourishing field, and the tendency is exponential in the centuries following the composition of the Tattvacintamani,

\footnotetext{
${ }^{1}$ A relatively recent account of earlier definitions, beginning with Vidyabhushana's pioneering History of Indian Logic (Calcutta, 1921) can be found in Wada (2001, 2007), who also makes a new attempt at a global definition, centered on the idea of "relation" (sambandha).
}

Jonathan Duquette

jd861@cam.ac.uk

Hugo David

hugo.david@efeo.net

1 École française d'Extrême-Orient, 22 Avenue du Président Wilson, 75116 Paris, France

2 French Institute of Pondicherry, 11 St-Louis Street, Pondicherry 605001, India

3 Faculty of Asian and Middle Eastern Studies, University of Cambridge, Cambridge, UK 
Gangeśa's magnum opus. ${ }^{2}$ Many specific features unmistakably characterise NavyaNyāya works, which have often been enumerated: an increasing attention to the crafting of elaborate definitions, the introduction of a new technicity in the philosophical language, the prominence of epistemological reflection (especially visible in the reorganisation of Nyāya-Vaiśeșika material following the four "means of valid knowledge" in Gangeśa's work), as well as the increasing popularity of new literary genres such as the krodapatra ("short essay" on a specific topic). All this clearly points to the emergence of a new "style" of philosophising in India in the beginning of the second millennium, that would eventually pervade all philosophical schools active at that time in the subcontinent. ${ }^{3}$ Such a reorganisation of philosophical discourse along the lines fixed by Navya-Naiyāyikas contributed to shape virtually every Indian knowledge system in the late pre-modernity, and can only be compared, in importance and impact, to transformations triggered by the advent of Buddhist logic in India in the 6th-7th century. All essays in this issue contribute, in various ways, to define this new style and to determine how philosophers of all doctrinal tendencies reacted to the conceptual revolution taking place in the field of logic and "systematics". 4

For one might ask, what exactly is "new" in "New Logic", and how much of it, precisely, pertains to "logic" alone? In his 1955 essay "Logic in India", one of the pioneers in the field, Daniel H.H. Ingalls, isolated three main innovations of NavyaNyāya with respect to the earlier, "ancient" (prācīna) Nyāya school: "a new method of universalization, rendered possible by the concept of limitation (avacchedakatā); the discovery of a number of laws similar to the theorems of propositional logic; a new interest in the definition of relations and the use of these relations in operations of considerable complexity". If no one can deny that these represent, indeed, significant conceptual innovations, the fact that they are restricted to "logic" in the strictest sense is typical of Navya-Nyāya studies in Ingalls' time. Are these technical innovations accompanied by similar ones in the various fields where logic is applied? Are they just providing new formulations for ancient views, or on the contrary, do they open up new thought possibilities, hitherto unexplored due to logical limitations ${ }^{6}$ ? Such crucial questions can be addressed following two strategies, both of which are well represented in this issue.

\footnotetext{
${ }^{2}$ For an overview, see Bhattacharya (1952) and Bhattacharya (1958).

3 On the idea of a new "style" of philosophising emerging with Navya-Nyāya, see Ganeri (2011, pp. 46), who suggestively (though somewhat anachronistically) compares what he calls the "new research programme for philosophy" introduced by neo-logicians after Raghunātha Siromani (end of the 15th century) to the "linguistic turn" that gave birth to Anglo-American analytical philosophy in the beginning of the 20th century.

4 For the use of the word "systematics" to designate Vaiśeșika, see Foucher (1949).

5 Ingalls (1955), reprinted in Ganeri (2017 [2001]), p. 113.

6 The question whether novelty of style was accompanied by "newness of substance" is paradigmatically asked by Sheldon Pollock in his 2001 essay on "New Intellectuals in Seventeenth-century India", repeatedly discussed in this issue. Pollock's contrast between the "extraordinary innovation in style" (p. 11) introduced by Navya-Nyāya and the "traditionalism of problematics themselves" (p. 12) sometimes attracted unilateral rejection from specialists in the field. Ganeri's 2011 book, with its strong emphasis on the radical modernity of "new philosophers" such as Raghunātha Siromaṇi, explicitly opposes Pollock's idea. For another contrasting view, see Patil (2011) and Patil (2013, pp. 102-117). As several essays in
} 
The first is to adopt the point of view of the Navya-Naiyāyikas themselves, and to track in their works cases where logical analysis allowed new philosophical problems to emerge, or at the very least, new answers to be given to old ones. Nilanjan Das' essay, which opens the volume, is a good example of such an approach. Focussing on Gangeśa and his early followers (his son Vardhamāna and the great 15th-century Mithilā commentator Jayadeva/Pakṣadhara Miśra), Das examines cases of what contemporary analytical philosophy calls "epistemic luck", a classical issue of post-Gettier analytical epistemology. What happens if a true theoretical judgement like "There is fire on the mountain" arises by way of a faulty reasoning (if we confuse mist for smoke, for instance, but an invisible fire happens to be there at the back of the mountain), or if the belief that "There is a pot in the room nearby" is produced by wrong verbal testimony (if somebody lies making this statement, while wrongly believing the room to be empty)? Are the means by which we reach true knowledge or belief essential to its definition as "true knowledge", or not? Das' article convincingly shows that, if generally older Nyāya epistemology does not consider cases of epistemic luck as genuine cases of (inferential or verbal) "true knowledge" (pramā), this idea is somehow accommodated by the "epistemic localism" advocated by the New school, beginning with Gangeśa. By a careful reading of selected passages of the Tattvacintamani's sections on inference and verbal testimony, Das shows that the way in which we come to a certain conclusion (i.e. the causal complex leading to the final awareness of the cognised object) is not as essential to "New" logicians as it was to "Old" Naiyāyikas, for whom a wrong inference - be it a "lucky" one-essentially remains a source of error. Just as an erring wanderer reaching his goal by chance reaches it nevertheless, knowledge acquired by faulty means cannot be firmly excluded from the realm of "true knowledge".

Another approach, particularly well represented in this volume, consists in investigating how Navya-Nyāya interacted, throughout its history, with other, contemporary thought systems. More than half of the essays are devoted to the diffusion of Navya-Nyāya ideas beyond the limits of the Nyāya-Vaiśeșika school proper into the fields of philosophical grammar and linguistics (Vyākaraṇa), Vedic exegesis (Mīmāṃsā) and Vedāntic theology. Interestingly, this "disciplinary" expansion coincides with a geographic diffusion of neo-logical studies beyond their place of origin in North-Eastern India (Mithilā and Bengal) into more Central and Southern parts of the subcontinent, a process investigated here for the first time on a significantly large scale. ${ }^{7}$ Was this, however, just a matter of adapting a specific terminology or conceptual toolkit-“delimitors" (avacchedaka), "circumscribers" of properties (nirüpaka), and so forth-, or did the confrontation with "new" logic also pave the way for decisive doctrinal evolutions? Furthermore, how deep was this

Footnote 6 continued

this volume clearly show, addressing Pollock's views requires a nuanced approach, and an assessment case by case that takes into account the variety of Sanskrit sources and their intellectual contexts. For early attempts in the fields of Mīmāṃsā and Alaṃkāraśāstra, see McCrea (2002) and Bronner (2002).

${ }^{7}$ For preliminary research on this process, see Bronkhorst et al. (2013), who deal with the specific case of Benares. 
penetration of Navya-Nyāya in South India? Did it durably pervade the South Indian philosophical landscape, or was it just limited to a few individuals? Finally, was such an influence only one-way, or was the neo-logician tradition itself affected in return by its spread beyond Nyāya-Vaiśeșika circles and their North-Eastern strongholds? Is it, in fact, correct to speak here of an "influence", or are we rather dealing with parallel evolutions?

The second essay, by Michael Williams, deals with Gangeśa's earliest and most famous critic, the South Indian Mādhva philosopher Vyāsatīrtha (end of the 15thbeginning of the 16th century). Williams' conclusion is clear: the confrontation of the two philosophers was not a matter of borrowing a logical "language", but was "philosophically productive". As he shows, Vyāsatīrtha's encounter with Gañgeśa also played a crucial role in the diffusion of Navya-Nyāya doctrines from Mithilā into South India, through the creation of new poles of logical studies in Vijayanagar and, after the fall of the Empire, as far South as Thanjavur. The main focus of the essay is Vyāsatīrtha's theory of "empty terms", i.e. linguistic expressions referring to fictitious entities such as the "golden mountain" or-to use Indian stock examples - the "hare's horn" or the "son of a barren woman", which do not have any referent in the real world. Can one meaningfully use such terms to build a true judgement like "The golden mountain does not exist"? A major contribution of Williams' study is to show that, somewhat unlike what happens in the obviously parallel debate on empty terms in early 20th-century logical theory (Meinong, Russell, etc.), for Vyāsatīrtha the problem of a cognition of fictitious entities is at work in multiple conceptual nexuses: the theory of illusory perception (how far can the silver mistakenly perceived in the mother-of-pearl be said to be "inexistent"?), the logic of "universal-negative" (kevalavyatirekin) inferences, and inferential judgements about non-existent subjects (such as: "The son of a barren woman is mute"). Vyāsatīrtha's recourse, in all these contexts, to "substrate-free properties" (anāśritadharma, i.e. properties that can exist without a locus) certainly builds on earlier theories such as Jayatīrtha's, but only an in-depth confrontation with Gangeśa's ideas could allow the great Mādhva philosopher to articulate the three domains in a fully-fledged - and equally realist! - theory of empty terms.

If Mādhva Vedānta might be the first philosophical school to systematically (and critically) address conceptual innovations introduced by Navya-Nyāya philosophers, the effort quickly spread to other trends of Vedānta as well. Duquette's essay deals with the Śaiva Vedānta works of Appaya Dīkșita (1520-1593?), another celebrated South Indian philosopher, and the first interactions with Navya-Nyāya of the nascent school of Śivādvaita theology, usually traced back to Śrīkaṇtha's commentary on the Brahmasutras. The essay focusses on the "inference of God" (iśvarānumāna), by which Naiyāyika authors claim to establish the existence of a Creator of the universe by rational means. Without denying the existence of such a Creator in itself, Appaya, like all Vedāntins (dualists and non-dualists alike), considers that the existence of Íśvara cannot be established by any inference, but only through Scripture (āgama, śāstra). By a careful reading of passages from Appaya's magnum opus in the field, the Śivārkamanidīpikā, Duquette gives evidence for Appaya's two-fold legacy: on the one hand, Gangeśa and his early commentators, who provide an up-to-date version of the Naiyāyika "inference of God", fully 
compliant with the standards of neo-logical inference theory; on the other, Vyāsatīrtha, the Mādhva philosopher, who already proposed a detailed critique of that inference in the Tarkatāndava. The core of Duquette's contribution is to demonstrate that Appaya's "revision" of Gangeśa's inference does not entirely rely on Vyāsatīrtha's, but rather presupposes a deep engagement with the Navya-Nyāya tradition itself. This is not just one more hint at the extent of learning of this admirable South Indian polymath; this case study also suggests that the level of logical studies in South India in the 16th century might have been far superior indeed to what is usually accepted. Though this hypothesis will need to be confirmed by further studies, Duquette's parallel observations regarding other trends of Śaiva philosophy (Umāpati Śivācārya) or Advaita philosophers like Nṛsiṃhāśrama (possibly an older contemporary of Appaya, also from South India) clearly point to that direction as well.

In a different vein, but on a related topic, Nirmalya Guha's essay turns to two scholars active further North, in Benares, belonging to the non-dualist (Advaita) school of Vedānta, namely Madhusūdana Sarasvatī (16th century, perhaps a younger contemporary of Appaya Dīkșita) and his follower Brahmānanda Sarasvatī (18th century), the author of two commentaries on the seminal "Proof of NonDuality" (Advaitasiddhi). As is well-known, Madhusūdana's Advaitasiddhi is essentially a response to Vyāsatīrtha's critique of Advaita in the Nyāyāmrta, and therefore follows in the latter's path by consistently engaging with Navya-Nyāya logic and metaphysics. In fact, it is often said that Madhusūdana himself originated from Bengal and studied under reputed Navya-Nyāya teachers in Navadvīpa. ${ }^{8}$ The article deals with an interesting debate between those late Advaitins and Naiyāyikas on the interpretation of co-referentiality (sāmānādhikaranya) in the context of Padmapāda's inference of ontological falsity (mithyātva). The attribution of a property to a certain subject in a co-referential sentence like "This pot is black" (nīlo ghațh) is interpreted in two different ways by the two schools. The typical Nyāya analysis in terms of inherence (samavāya) is rejected by Advaitins, who prefer an interpretation in terms of identity-and-difference (bhedābheda): identity, because the two words in the sentence refer to the same thing: the black pot; but also difference, for the way they are cognised is not the same (a pot considered "as a pot" is not quite the same thing as a pot considered "as a black entity", though both are identical, ontologically speaking). With the help of his own original logical notation, Guha shows how Brahmānanda revisits this old debate by making use of his time's logical tools, thus producing analyses of great subtlety.

Still in the context of premodern Benares, Bogdan Diaconescu's essay on Khandadeva (active in the first half of the 17th century) explores to what extent the field of Vedic exegesis (Mīmāmsāa) was affected, in its turn, by the increasing prominence of the "new idiom" of neo-logicians. According to Diaconescu, the influence of Navya-Nyāya on Mīmāmsāa becomes visible for the first time in the context of 16th-century South India, against the backdrop of intra-Vedāntic controversies between dualists and non-dualists: the (mainly) non-dualist Appaya Dīkșita and his great rival, the dualist Vijayīndratīrtha of Thanjavur, both authored

\footnotetext{
${ }^{8}$ For a survey of secondary literature on this topic, see Pellegrini (2014, p. 283).
} 
works of Mīmāṃsā making abundant use of Navya-Nyāya terminology and methods. This tendency intensified in the 17th century especially in Benares, in the wake of Khandudeva and his lineage, giving rise to what is sometimes called "Navya-Mīmāmsā̄", "New Exegesis". The article reaches the same conclusion suggested by Guha's analysis of Brahmānanda, namely that in some fields the "innovations" inspired by Navya-Nyāya are not of a radical nature: they are "new formulations" for "old topics". Nor is the attitude of "new" intellectuals systematically critical towards the past: "new" Mīmāṃsakas rather place themselves in the continuity of a century-long tradition of critical engagement with the earlier tradition within the school. This is well illustrated in Diaconescu's careful reconstruction of the debate on the "principal qualificand" (mukhyaviśeșana) of a sentence in Khaṇ̣adeva's work. As is well-known, the (Bhātța-)Mīmāṃsaka view of "effectuation" (bhāvanā) as the main element denoted in a sentence differs from the views of both Nyāya and Pāninian grammar on the subject. Khaṇdadeva's defence of the Mīmāmsā point of view leads him to elaborate reflections on concepts at stake in verbal cognition, like the concept of "agency" (kartrtva), defined as an indivisible property (akhandopādhi). Besides the undeniable gain in subtlety and precision, these developments also seem to suggest that conceptual tools introduced by neo-logicians (the rigorous classification of properties, relational abstracts, etc.) provided a sort of common platform for scholarly debate in this period. Such an "oecumenic" common ground for scholarly exchange was not available - or not to the same degree - at earlier stages in the debate, where the particularities of each tradition could not be overcome so easily.

The last essay in the issue, by Samuel Wright, adopts a different perspective and looks at the evolution of Nyāya in colonial Bengal from the point of view of paṇit networks and manuscript circulation. This focus on social history rather than doctrinal contents, though not entirely unprecedented, is nevertheless quite novel in Navya-Nyāya studies, and adds an important dimension to research on the texts themselves. This study is also important as it brings to the foreground the question of manuscript transmission, quite crucial in a domain where a substantial part of the corpus is still unpublished. Wright first gives us a glimpse of scholarly networks in colonial Bengal, by closely examining a series of historical documents: travel accounts, legal agreements, letters, etc. Turning then to "manuscript economy", Wright's paper maps the localisation of texts by fourteen Nyāya pandits from the 18th and early 19th century and the repartition of Nyāya works in a major South Indian manuscript repository in Thanjavur. Of particular interest is the destiny of the krodapatra, perhaps the most typical literary product of Navya-Nyāya circles. As shown by Wright, such works by 19th-century authors abound in manuscript repositories in Bengal. By contrast, they are practically absent from the collection in Thanjavur, the bulk of which is constituted by "classics" from the 16th-17th centuries, such as the works of Gadādhara Bhațāaārya. Does this tell us something of the evolution of Nyāya as an intellectual discipline? It certainly does for Wright, who concludes that the prevalence of such works in 19th-century Bengal restricted the circulation of Nyāya manuscripts in the South, due to the relative disinterest of the South Indian scholarly community for such a highly specialised genre. There might be optical effects here, too. As pointed out by Wright himself, krodapatras written in 
the 18th century are relatively rare in Bengali manuscript repositories (at least, those for which a catalogue is available), but historical research from the 1950s still mentions them in good number in private collections. Still, the data carefully assembled here generally seem to corroborate Wright's conclusion that the krodapatra, so popular in Bengal in the colonial period, never attained such a prominence in South India. They also clearly make Wright's point that a true history of Navya-Nyāya in the colonial period will include greater attention to social practices than has been given in the past.

\section{References}

Bhattacharya, D. (1952). Bañge Navyanyāyacarcā. Calcutta: Bangiya Sahitya Parishat (in Bengali).

Bhattacharya, D. (1958). History of Navya-Nyāya in Mithilā. Darbhanga: Mithilā Institute of Post Graduate Studies and Research in Sanskrit Learning.

Bronkhorst, J., Diaconescu, B., \& Kulkarni, M. (2013). The arrival of Navyanyāya techniques in Varanasi. In K. Pandikattu \& B. Pichalakkattu (Eds.), An Indian ending. Rediscovering the grandeur of Indian heritage for a sustainable future. Essays in Honour of Prof. Dr. John Vattanky on completing eighty years (pp. 73-109). New Delhi: Serials Publications.

Bronner, Y. (2002). What is new and what is Navya: Sanskrit poetics on the eve of colonialism. Journal of Indian Philosophy, 30, 441-462.

Foucher, A. (1949). Le Compendium des Topiques (Tarka-Samgraha) d'Annambhatta avec des extraits de trois commentaires indiens. Éléments de systématique et de logique indiennes. Paris: AdrienMaisonneuve.

Ganeri, J. (2011). The lost age of reason. Philosophy in early modern India (1450-1700). Oxford: Oxford University Press (The Oxford History of Philosophy).

Ganeri, J. (Ed.) (2017 [2001]). Indian logic. A reader. Richmond: Curzon (Indian reprint: Replika Press).

Ingalls, D. H. H. (1955). Logic in India. In Ganeri (2017 [2001]) (pp. 110-116) (originally published as an entry in the Encyclopedia Britannica, 14th ed. Vol. 8, pp. 311-312).

McCrea, L. (2002). Novelty of form and novelty of substance in seventeenth-century Mīmāṃsā. Journal of Indian Philosophy, 30, 481-494.

Patil, P. (2011). The end of the ends of man? In Y. Bronner, W. Cox, \& L. McCrea (Eds.), South Asian texts in history: Critical engagements with Sheldon Pollock (pp. 293-305). Ann Arbor: Association for Asian Studies.

Patil, P. (2013). The historical rhythms of the Nyāya-Vaiśeșika knowledge system. In E. Franco (Ed.), Periodization and historiography in Indian philosophy (pp. 91-127). Vienna: University of Vienna (Publications of the De Nobili Research Library 37).

Pellegrini, G. (2014). 'Old is gold!' Madhusūdana Sarasvatī’s way of referring to earlier textual tradition. Journal of Indian Philosophy, 43, 277-334.

Pollock, S. (2001). New intellectuals in seventeenth-century India. The Indian Economic and Social History Review, 38(1), 3-31.

Vidyabhusana, S. C. (1921). A history of Indian logic (Ancient, Mediaeval and Modern Schools). Calcutta: Calcutta University (reprint Delhi: Motilal Banarsidass, 1971).

Wada, T. (2001). The analytical method of Navya-Nyāya. Journal of Indian Philosophy, 29, 519-530.

Wada, T. (2007). The analytical method of Navya-Nyāya. Groningen: Egbert Forsten.

Publisher's Note Springer Nature remains neutral with regard to jurisdictional claims in published maps and institutional affiliations. 